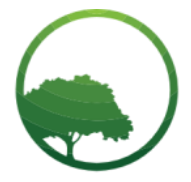

Research in Business \& Social Science

IJRBS VOL 9 NO 2 ISSN: 2147-4478

\title{
Factors affecting customer behavior in telecommunication industry
}

\author{
Mbarek Rahmoun \\ King Abdulaziz University, Kingdom of Saudi Arabia
}

Crossref

\begin{tabular}{l} 
A R T I C L E I N F O \\
\hline Article history: \\
Received 25 December 19 \\
Received in revised form 05 Feb 20 \\
Accepted 13 Feb 20 \\
\hline Keywords: \\
Customer experience, Customer \\
service, Customer behavior, \\
Service quality, Customer satisfaction \\
Telecom services \\
JEL Classification: \\
M30, L10
\end{tabular}

\begin{abstract}
A B S T R A C T
Marketing and strategy research has given a lot of importance to the study of product and service quality improvement. This has been widely studied in the literature as an appropriate competitive strategy to ensure customer satisfaction in the marketplace and gain a sustainable competitive advantage. In this paper, first, we have opted for an extensive review of marketing literature, quality of service and consumer satisfaction. Next, we propose to determine the factors that may affect customer satisfaction in the telecommunications industry in Tunisia. Indeed, each organization chooses to succeed in its strategy of satisfying its customers and to prevent the risk of losing them. Our empirical results indicate that most customers are satisfied with the quality of service provided to them, and most customers believe that Tunisie Telecom's service quality is above their expectations. Quality of reception at the counters of Tunisie Telecom's agencies is the key element for the success of the quality improvement project and is the major factor that can strongly influence client satisfaction and behavior.
\end{abstract}

(C) 2020 by the authors. Licensee BSC International Publishing, Istanbul, Turkey. This article is an open access article distributed under the terms and conditions of the Creative Commons Attribution (CC BY) license (http://creativecommons.org/licenses/by/4.0/).

\section{Introduction}

Defining service quality is a difficult task, because of the intangibility of offered services. As such, measuring its performance, on the one hand, and its heterogeneity between people and situations, on the other, is implicit at best. The service sector occupies a predominant place in the economic system. Services are essentially processes and unlike companies that offer tangible goods, service companies do not offer any pre-established production line. Service quality is only observable in the consumption result because there is no way to ensure quality of services before they are consumed. Indeed, the consumer is able to spot almost all defects, since services are produced and consumed at the same time. In addition, in the service sector the cost of non-quality is much higher than in the industrial sector. Clients of telecommunication services explore how they compare with each other (Parasuraman et al., 1988). However, the service quality is frequently quantified by utilizing instruments created by SERVQUAL (Parasuraman et al., 1985).

Nowadays, worldwide, the notion of quality has taken momentum in business management. Indeed, consumer demand for quality has become more and more astute in a globalized economy, internationalized markets and intense competition. In this regard, the survival and prosperity of businesses will depend more than ever on their ability to identify consumer demands, determine the "internal causes responsible for customer dissatisfaction", and ensure an improved quality to be able to provide services that meet consumer needs. The notion of quality is a comprehensive concept as it applies to all services, goods, raw and manufactured products.

The prime objective of the research is to evaluate the impact of service quality dimensions on customer satisfaction in the sector of telecommunication. This study aims to support existing literature to improve the service quality of telecom companies provided to their customers in Tunisia.

* Corresponding author. ORCID ID: 0000-0002-0333-9056 


\section{Literature review}

Quality in services has been the subject of several controversies that bear on the very nature of the activity, that is the service. The notion of quality can have different dimensions, depending on the will of the company's managers, the sector of activity and the geographical location. Parasuraman et al. (1988) defined service quality as "the gap between the customer's expectations of service and the perception of quality after using the service". According to Gijsenberg et al. (2015), "Quality is what makes the customer happy". This definition opens the way for two possible methodological perspectives:

-Either by hammering the target consumers with communication tools to encourage them to like the product.

-Either by trying to solve the problems experienced by customers in order to satisfy them.

Accordingly, it is therefore a question of implementing total quality, yet interesting is to implement the means to obtain this quality. The latter perspective bears on a concern for product safety. Fornell et al. (2010) define quality as "(firm) ability to satisfy the needs of its users". Juran (1988) defined quality as the absence of defects in the product and the likelihood that product characteristics meet customer requirements. Ishikawa (1984) defined quality as a guarantee that the product is reliable in the eyes of consumers. Indeed, it is essential that quality reflects the explicit and implicit needs of customers. In this regard, customers need to trust the company's ability to provide the desired quality in a consistent way. For Crosby (1979), quality is compliance with specifications. Juran (1988) defines quality as the company's commitment to satisfy its customers. According to the author, a service reaches higher levels of excellence when it meets the needs and demands of a target clientele. Dominique Collet defined quality as "conformity to the real needs of the customer at the fairest price". Indeed, this definition puts an emphasis on "conformity" which is defined by ISO 8402 as meeting the specified requirements. In addition, quality is considered a factor of success, efficiency and productivity as well as a key dimension of competitiveness. Customer satisfaction is a standout amongst the main MOST research subjects for the past few decades (Gallifa and Batalle, 2010; Mbarek et al., 2017).

For operational durability, every company needs to achieve and maintain the desired quality at an optimal cost. To this end, all company staff should be involved; hence quality is everyone's business. Nowadays, a lot of research is starting to study neuroscientific approaches to measure the customer experience (Lewinski, 2015; Simon, 2019).

\section{Service quality in public institutions}

For public institutions, quality comes from an essential trade-off between expectations of beneficiaries, public policies, strategies and mission statement. Indeed, for a given service, the desired service is defined in terms of:

a benchmark service (performance level),

a requirement level,

and, possibly, a threshold above or below which the service is unacceptable.

For example, a quantified and a measurable time frame, specified in a commitment, defines a service level. Service levels are generally assessed by indicators that are significant for beneficiaries. They can be communicated externally or used only as an internal reference for progress. The result of this trade-off will determine the level of quality sought. In most cases, this level needs to be clarified for all actors. By the same token, it is obvious that quality cannot be defined in itself or for oneself, but often for the beneficiary. The needs of this/these beneficiary(ies) vary over time, as well as the environment and context. Quantity is, therefore, an evolving concept. To ensure operational success, there are several criteria to consider. First of all, every company should adopt a project that brings together all the dimensions of quality, with the objective of satisfying customers. Second, it should not be forgotten that in the field of service, quality essentially depends on the quality of customer and staff interaction. It should be noted that, given the spectacular development of services, it is time for managers to study consumer needs, to consider whether the thinking and decision-making methods developed in the context of products are adapted to those of services, to understand the specificity of services and to draw conclusions and translate them into the company's marketing policy.

Public service companies, in particular those operating in the telecommunications sector, face now fierce competition and criticism of their purpose. It is very important to conceptualize motivation schemes: customers are rewarded with their concretization of performance results in a ski challenge, such as becoming a "king of the mountain" (Bijmolt and Verhoef 2016). They should rethink their relationship with their customers by committing themselves to uphold certain quality standards in order to meet their needs. The survival of these companies depends both on their economic profitability and on their customers' perception of the quality and efficiency of the service they offer. However, in a competitive context, success no longer depends on the intrinsic quality of products or services, but also on their delivery. It is in within this context that the telecommunications sector, which plays a leading role in the development of the Tunisian economy, is called upon to adapt itself as soon as possible to the increasingly becoming stern requirements of the international market. This sector has sought the promotion of different service categories for citizens, especially those who need its help and support most. To this end, telecom service providers should constantly seek quality. In this regard, Tunisie Telecom prioritized the adoption of quality measures within its reform framework and set up in turn the main lines of its quality policy to ensure consistency over time. 


\section{The importance of service quality in the telecommunications sector}

Several researchers and students of consumer behavior showed an increasing interest in the telecommunications sector. Accordingly, our study raises similar concerns and takes the semi-public "Tunisie Télécom" as a case study in order to check our research hypotheses and problem. Economic liberalization, the generalized globalization movement and the exacerbation of competition witness the turbulence and complexity of today's Tunisian economy. Therefore, in a new context of competition and openness to the outside world, new rules have become essential for any company seeking competitiveness and profitability.

Customer experience is your customers' holistic perception of their experience with your business or brand. Today we are witnessing a change in customer behavior that is becoming more and more demanding and adopts multi-channel behavior (Filser, 2001; Belvaux, 2006; Poncin, 2008).

The search for performance and the quest for excellence are among the priority objectives of any company. To reach these objectives, companies then highlight quality as an essential concern. Indeed, the survival and prosperity of businesses will depend more than ever on their ability to provide services and products that meet consumer needs. Under these conditions, companies should seek to satisfy all stakeholders, namely customers, employees, owners, subcontractors and management itself. Then, our research problem is how to achieve a successful quality policy for telecom services. It should be noted that, given the spectacular development of services, it is time for managers to study consumer needs, to consider whether the thinking and decision-making methods developed in the context of products are adapted to those of services, to understand the specificity of services and to draw conclusions and translate them into the company's marketing policy.

Nowadays, public service companies, in particular telecommunications providers, are subject to fierce competition and concerns about their presence. Therefore, we formulate the following hypotheses:

H1- Most customers are satisfied with the quality of service provided to them.

H2-Most customers believe that Tunisie Telecom's service quality is above their expectations.

H3-Quality of reception at the counters of Tunisie Telecom's agencies is the key element for the success of the quality improvement project.

\section{Research and Methodology}

In this section, we will test our research hypotheses. The objective of this research is to identify the factors that impacted the customer satisfaction in the telecommunications sector. We used the quotation method. Our research methodology consists in interviewing 100 customers leaving Tunisie Telecom's agencies by means of a questionnaire. Questionnaires are known to be instruments that allow for the collection of both quantitative and qualitative data. Moreover, semi-directive questionnaires tend to combine flexibility and analysis. In addition, this method allows us to obtain reliable responses insofar as the presence of the interviewer tends to create a favorable and a motivating atmosphere, the possibility to reformulate or explain questions or statements that are not clear to the interviewee and to collect responses in the planned order.

Flat or simple sorting yields outputs in the form of frequency in absolute values and percentages. Indeed, this technique allowed us to study the distribution of the responses of our sample on the chosen variable.

Flat sorting of socio-demographic variables

Table 1: Education

\begin{tabular}{llll}
\hline & Frequency & Percent & Cumulative percent \\
\hline Primary & 6 & 6,0 & 6,0 \\
\hline Secondary & 16 & 16,0 & 22,0 \\
\hline University & 78 & 78,0 & 100,0 \\
\hline Total & 100 & 100,0 & \\
\hline
\end{tabular}

Based on the results displayed in the table 1, it can be seen that $78 \%$ of the sample have a university education level, $16 \%$ have a secondary education level and $6 \%$ have a primary education level. This latter group needed a specific personal approach to make the answers and statements of the questionnaire comprehensible to them. 
Table 2: Age

\begin{tabular}{llll}
\hline & Frequency & Percent & Cumulative Percent \\
\hline $\mathbf{- 2 0}$ & 5 & 5,0 & 5,0 \\
\hline $\mathbf{2 0 - 3 0}$ & 65 & 65,0 & 70,0 \\
\hline $\mathbf{3 0 - 4 0}$ & 17 & 17,0 & 87,0 \\
\hline $\mathbf{4 0 +}$ & 13 & 13,0 & 100,0 \\
\hline Total & 100 & 100,0 & \\
\hline
\end{tabular}

As shown in the table 2, we see that $65 \%$ of our sample is between 20 and 30 years old, $17 \%$ between 30 and 40 years old, $13 \%$ are over 40 years old and only $5 \%$ are under 20 years old.

Table 3: Gender

Frequency percent Cumulative percent

\begin{tabular}{lccc}
\hline Male & 58 & 58,0 & 58,0 \\
\hline Female & 42 & 42,0 & 100 \\
\hline Total & 100 & 100 &
\end{tabular}

As can be seen in Table 3, 58\% of the sample are males, while $42 \%$ are females.

\section{Degree of customer satisfaction and expectations}

In this section, we will first present the results on Tunisie Telecom customer satisfaction. Then, we will present their expectations.

Table 4: Satisfaction

\begin{tabular}{lccl}
\hline Service quality & Frequency & Percent & $\begin{array}{l}\text { Cumulative } \\
\text { percent }\end{array}$ \\
\hline Satisfactory & 56 & 56,0 & 56,0 \\
\hline Fairly satisfactory & 27 & 27,0 & 83,0 \\
\hline Unsatisfactory & 17 & 17,0 & 100,0 \\
\hline Total & 100 & 100,0 & \\
\hline
\end{tabular}

The table 4 reports the results on customer satisfaction in general. We can see that $56 \%$ of the interviewees are satisfied with the service provided to them and $27 \%$ were fairly satisfied. However, $17 \%$ were dissatisfied. Tunisie Telecom should investigate this unsatisfaction rate as it, even if it is low, may considerably affect Tunisie Telecom's reputation and above all opens the way for competitors to step in and gain that share of the market. Therefore, our first hypothesis, "most customers are satisfied with the quality of service provided to them", is confirmed.

Comparing the overall satisfaction of clients with their expectations yielded the following results:

Table 5: Customer expectations

\begin{tabular}{llll}
\hline & Frequency & Valid percent & Cumulative percent \\
\hline Quality below expectations & 41 & 41.0 & 41.0 \\
\hline Quality meets expectations & 35 & 35.0 & 76.0 \\
\hline Quality above expectations & 24 & 24.0 & 100.0 \\
\hline
\end{tabular}


As shown in the table 5, we see that $24 \%$ of the sample believe that Tunisie Télécom's service quality is above their expectations, $35 \%$ of respondents expressed their satisfaction with the quality of the service provided to them. Almost half of the interviewees, $41 \%$, are disappointed with the quality of the services offered by Tunisie Télécom, which is below their expectations. Therefore, we reject our hypothesis 2 "Most customers believe that the quality of service of Tunisie Télécom is above their expectations". These percentages represent a loss of revenue for Tunisie Télécom, since these customers will likely look for a higher level of service than they expected. This confirms the existence of a gap between what Tunisie Télécom really offers and customer expectations. Probably, this state of affairs may have resulted from a poorly defined customer service and inadequate customer relationship management.

Degree of importance of quality criteria according to customers

Table 6: Degree of importance of quality criteria according to customers

$\begin{array}{ll}\text { Criteria } & \text { Importance }\end{array}$

\begin{tabular}{ll}
\hline Reception in general & $71 \%$ \\
\hline Service speed & $69 \%$ \\
\hline Reliability of information given to customers & $65 \%$ \\
\hline Quick processing of complaints & $60 \%$ \\
\hline Office design & $58 \%$ \\
\hline Staff friendliness & $55 \%$ \\
\hline
\end{tabular}

As shown in the table 6, we see that data would allow us to define the criteria judged by customers as the most important to assess the quality of Tunisie Telecoms services. Indeed, $71 \%$ confirmed that reception in general plays a major role in the overall evaluation of the service. Next comes service speed with $69 \%$ respondents believe it is important. Third is the reliability of the information given to customers. This latter criterion tends to foster trust between customer and the provider. Fourth comes the rapid processing of complaints. In general, it seems that four factors are likely to affect the quality of Tunisia Telecom's service: reception, service speed, quality of the information provided to customers and the quick processing of complaints. Therefore, we confirm our hypothesis 3, "quality of reception at the counters of Tunisia Télécom's agencies is the key element for the success of the quality improvement project".

\section{Conclusion}

To ensure the operational success of telecommunications companies, several criteria have to be considered. First of all, every company should adopt a project that brings together all the dimensions of quality, with the aim of satisfying customers. Second, it should not be forgotten that in the field of services, quality essentially depends on the quality of customer and staff interaction. They need to rebalance the relationship with their customers by committing themselves to respect certain quality standards as a way to meet their needs. Survival of these companies depends both on their economic profitability and on their customers' perception of the quality and efficiency of the service they offer. However, in a competitive context, success not only depends on the intrinsic quality of products or services, but also on the way these are presented and delivered. Importantly, welcoming customers, improving service quality, promoting a modern image, reducing waiting times, improving readability of customer service forms and deadlines for satisfying requests, and clarifying contracts terms need to be considered.

\section{References}

Belvaux, B. (2006). Du E-commerce au multi canal: les différentes implications d'Internet dans le processus d'achat du consommateur, Revue Française du Marketing, 209, 49- 68.

Bijmolt, T.H.A. and Verhoef. P. C. (2016). LoyaltyProgram: Current Insights, Analytical Challenges and Emerging Trends. in Handbook of Marketing Decision Models. Berend.

Crosby, P. B. (1979). Quality is Free. McGraw-Hill, New York.

Filser M. (2001). Commerce en magasin et e-commerce: les apports des modèles de choix du point de vente, Actes du 4ème colloque Etienne Thil, La Rochelle, Septembre.

Fornell, C., Rust, R. T. and Dekimpe, M.G. (2010). The Effect of Customer Satisfaction on Consumer Spending Growth. Journal of Marketing Research, 47 (February), 28-35.

Gallifa, J., \& Batallé, P. (2010). Student perceptions of service quality in a multicampus higher education system in Spain. Quality Assurance in Education, 18(2), 156- 170.

Gijsenberg, M.J., van Heerde, H.J., and Verhoef. P. C. (2015). Losses Loom Longer Than Gains: Modeling the Impact of Service Crisis on Perceived Service Quality over Time. Journal of Marketing Research, 52 (October), 642-56.

Ishikawa, K. and D. J. Lu. (1985). What is Quality Control? The Japanese Way. Prentice-Hall, Englewood Cliffs, NJ

Juran, J. M. (1988). Quality Control Handbook. McGraw-Hill, New York. 
Lewinski, Peter. (2015). Automated Facial Coding Software Outperforms People in Recognizing Neutral Faces as Neutral from Standardized Datasets. Frontiers in Psychology, 6, article 1386 http://doi.org/10.3389/fpsyg.2015.01386.

Parasuraman A, Zheitmal VA, Berry LL. (1985).Servqual: a conceptual model of service quality and its implications for future research. Journal of Marketing, 49(1):41-50.

Parasuraman, A., Zeithaml, V. A., \& Berry, L. L. (1988). Servqual. Journal of retailing, 64(1), 12-40.

Poncin I. (2008). Le comportement multi canal est-il une simple évolution ou constitue t-il une véritable révolution ?, Reflets et perspectives de la vie économique, 2, Tome XLVII, 43-51.

Rahmoun, M., Salim, M. and Kefi, A.(2017). Impact of perceived service quality on business customers satisfaction: An empirical study of tunisie telecom operators. International Journal of Current Research 9(2): 46407-46412.

Thomsen, T. (2019). 5 things you should know about tech today. Reimagination. News \& analysis. 